\title{
Rainfall Variations over Zhoushan during Last Four Decades
}

\author{
Liuzhu Wang1, Kuanke He ${ }^{2}$, Wangyuan Zhu' ${ }^{1}$, M. V. Subrahmanyam ${ }^{*}$ \\ ${ }^{1}$ School of Marine Science and Technology, Zhejiang Ocean University, Zhoushan, China \\ ${ }^{2}$ Zhoushan Meteorology, Zhoushan, China \\ Email: *mvsm.au@gmail.com
}

How to cite this paper: Wang, L.Z., He, K.K., Zhu, W.Y. and Subrahmanyam, M.V. (2019) Rainfall Variations over Zhoushan during Last Four Decades. Open Access Library Journal, 6: e5819.

https://doi.org/10.4236/oalib.1105819

Received: September 26, 2019

Accepted: October 25, 2019

Published: October 28, 2019

Copyright $\odot 2019$ by author(s) and Open Access Library Inc.

This work is licensed under the Creative Commons Attribution International License (CC BY 4.0).

http://creativecommons.org/licenses/by/4.0/

(c) (7) Open Access

\begin{abstract}
Rainfall is essential for the humanity as well as for agriculture. Zhoushan is an Island, which experiences different kinds of rainfall events, such as due to typhoon, local convection, topographic effects, etc. To find out the variations, we have chosen Global Precipitation Climatology Project (GPCP) merged rainfall data set over Zhoushan during the period 1979-2018. Monthly, seasonal, annual and decadal variations have been checked and find out there is an increasing trend in rainfall during the study period. All the seasonal variations are illustrating an increasing trend except spring season, which showing decreasing trend. Recent decade (2009-18) illustrating strong increase in rainfall, this may be due to heavy rainfall events increased during decade. To find out the heavy rainfall events, we have chosen few typhoons' rainfall during its life time, which clearly demonstrating that rainfall during the typhoon period. Zhoushan is experiencing heavy rainfall when the typhoon landfall over Zhejiang province also experiencing rainfall while typhoon passing through.
\end{abstract}

\section{Subject Areas}

Hydrology

\section{Keywords}

Rainfall, Zhoushan, Typhoon, Convectional Rainfall, Topographic Effect

\section{Introduction}

In the hydrological cycle, rainfall is one of the essential parameters for human as well as for plants and in the exchange process. The world's climate rainfall is an important parameter which changing and its effect being felt the world over due to global warming. According to climate models, rainfall/precipitation patterns 
will shift in two major ways. The first shift is in strengthening the current patterns, which means the wet regions would get wetter and dry regions would get drier. This is because warmer air as a result global warming traps more water vapour, and scientists predict that this additional water will fall in the already wet parts of the earth. The second shift is due to changes in atmospheric circulation, the narrow zones in seas and oceans along which storms travel, driven by prevailing winds because of storm tracks would move away from the equator and towards the poles.

Precipitation occurring due to typhoons is high in a shorter time, but the diurnal cycle is not fully understood. The typhoon induced precipitation is of interest for its destruction [1] and coastal regions are experiencing heavy rainfall which is similar to seasonal precipitation [2] [3]. The internal precipitation process is directly related to latent heat release during typhoon also depends on the intensity, duration and size of the typhoon [4] [5] [6]. Occurrence of precipitation on a particular day is connected with regional or large-scale thermal and dynamical conditions [7] and it has been studied using observations and model studies. Diurnal variations of precipitation have large differences between open oceans and the continents [8].

Convectional rainfall occurs when the insolation heats the earth's surface and causes water to evaporate and as it rises, it cools. The air reaches a point the water vapor condenses and turns back to a liquid form leads to the development of clouds. As the clouds continue to grow the weight of the water droplets can eventually lead to precipitation, since heating of the lower atmosphere produces available potential energy that can be released by convective overturning [7] [9] to produce convective precipitation. Over the oceanic areas deep convection reaches maximum in the early morning [10], however the cause for deep convection still debatable.

Presently available theories are: the dynamical processes of the differential radiative heating between the convective and the surrounding cloud-free region [11]; the upper level absorption of shortwave radiation leading to convective anvils during daytime and longwave cooling at cloud top at night, which influence relative humidity and stability [12]; due to nighttime longwave cooling, increase in relative humidity and reduced entrainment [8]; and the daily variations in the surface layer over the ocean is more complex mechanism [13] [14]. The inner and outer rainbands in the spiral rainbands divided according to their locations and characteristics [15]. Commonly known as thunderstorms, convective storms are the atmospheric phenomenon responsible for weather hazards such as lightning, heavy rain, hail, and tornadoes. The tendency of convective storms to generate these hazards depends in part on whether the convection organizes into mesoscale convective systems such as squall lines, or into the long-lived convective cells known as supercells; these storm types have unique dynamical structure that is largely controlled by the three-dimensional humidity, temperature, and wind in the environment of the developing convection. 
Orographic rainfall is rain that is produced from the lifting of moist air over a mountain. The moist air rises and cools, producing orographic clouds, which are the source of the rain. Most orographic rain falls upwind of the mountain range, with some also falling a short distance downwind. Orographic precipitation, also known as relief precipitation, typically affects mountainous areas near coastlines. This process can produce any type of precipitation, including snow, sleet, hail or freezing drizzle.

Zhoushan is located in the eastern China Sea, a subtropical marine climate, geographical regionalization. Zhoushan is warm and humid climate situated in the geographical co-ordinates between $29^{\circ} \mathrm{N}-32^{\circ} \mathrm{N} ; 121^{\circ} \mathrm{E}-123^{\circ} \mathrm{E}$ consisting of 1390 islands and rainfall is the main source of water resource. Zhoushan consisting of scattered islands, fresh water area is limited and rainfall is important and main source for living and agriculture. There are many factors that influence precipitation rate. Zhoushan experiences seasonal and annual variations. As Zhoushan is situated in the sea, the source of rainfall is having different types, such as convectional rain, topographic effect and due to typhoons occurring over northwestern Pacific Ocean. This work has been studied to understand the seasonal, annual rainfall pattern and the effect of typhoons on heavy rainfall occurred over Zhoushan.

\section{Data and Methodology}

Monthly rainfall data has been obtained from Global Precipitation Climatology Project (GPCP) merged rainfall data to check the monthly, seasonal, annual and decadal variations set over Zhoushan during the period 1979-2018. GPCP stands for Global Precipitation Climatology Project, was established by the World Climate Research Program (WCRP) to develop a more complete understanding of the spatial and temporal patterns of global precipitation. The general approach is to combine the precipitation information available from each of several sources into a final merged product, taking advantage of the strengths of each data type. GPCP provides ( $1^{\circ}$ spatial resolution) global precipitation products with satellite and gauge information [16]. We have chosen some typhoons to find out the rainfall pattern over Zhoushan during the typhoon time. Tropical Rainfall Measuring Mission (TRMM) data has been used to find out the daily rainfall occurred during the typhoon. TRMM-Multi-satellite Precipitation Analysis (TMPA) 3B42 precipitation product version 7 [17] covering the globe from $50^{\circ} \mathrm{S}$ to $50^{\circ} \mathrm{N}$ and has spatial resolution of $0.25^{\circ}$ grid. TRMM $3 \mathrm{~B} 42$ rainfall data has been frequently used for typhoon rainfall analysis regionally and globally [3] [18] [19]. We have chosen two different data sets for monthly and daily because, TRMM/ TMI data is better than GPCP for the daily data for the precipitation measurement of typhoon. For this study we used the typhoon track information from JTWC [20].

Calculation of Standardized anomalies:

We calculated the standardized anomalies for better understanding of sea- 
sonal, annual rainfall and presented. As it is well known that during the typhoon time heavy rainfall occurs, which almost seasonal rainfall is. The of standardized anomalies calculated as follows

$$
\begin{aligned}
& \text { Mean } \bar{x}=\frac{1}{n} \sum_{i=1}^{n} x_{i} \\
& \text { Standard deviation } \sigma=\sqrt{\frac{1}{n-1} \sum_{i=1}^{n}\left(x_{i}-\bar{x}\right)^{2}} \\
& \text { Standardized anomaly }=\frac{x-\bar{x}}{\sigma}
\end{aligned}
$$

where $x$ is the actual value, $n$ is the number of points.

\section{Results and Discussion}

\subsection{Monthly and Seasonal Variation of Rainfall over Zhoushan}

A composite monthly variation over Zhoushan is given in the Figure 1. June month clearly indicating higher rainfall and December month is the lowest. During the summer month of June, rainfall fall is higher due to monsoon prevails as well as the typhoons.

The rainfall pattern over Zhoushan is given in the Table 1. From the Table 1, it is clearly evident that the rainfall in the summer season is higher than other season. It is observed that during the summer season the typhoons land falling or passing through Zhoushan area are higher. Due to higher number of typhoons Zhoushan rainfall higher. However in the autumn season the rainfall due to typhoons are lower and in the winter and spring the affect of typhoon on

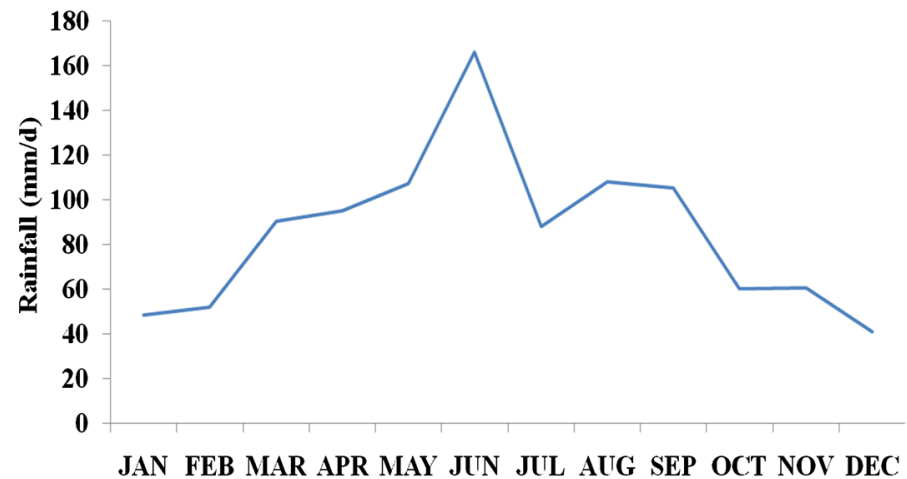

Figure 1. Composite monthly variation of rainfall $(\mathrm{mm} / \mathrm{d})$ over Zhoushan during the period 1979-2018.

Table 1. Mean rainfall $(\mathrm{mm})$ pattern over Zhoushan in relation to ENSO events during different seasons.

\begin{tabular}{ccccc}
\hline & Summer & Autumn & Winter & Spring \\
\hline El Nino & 126.4 & 74.2 & 54.6 & 92.9 \\
La Nina & 121.6 & 78.9 & 43.7 & 99.7 \\
Neutral & 113.1 & 72.2 & 43.8 & 100.4 \\
Over all & 120.7 & 75.2 & 47.5 & 97.5 \\
\hline
\end{tabular}


Zhoushan rainfall is minimal. In the spring time the rainfall is higher than winter and autumn seasons, this may be due to the temperature over Zhoushan is increasing, however cold air from the northern regions prevailing and due to warmer temperature and moisture in the air Zhoushan is experiencing the rainfall. During the winter season, the rainfall is occurring due to northern cold air prevailing and due to the topographic effect over Zhoushan the air is moving up wards and forming as cloud to produce rainfall.

Figure 2 depicts the standardized anomalies of four seasonal (summer, autumn, winter and spring) rainfall. Seasonal variations are indicating an increasing trend

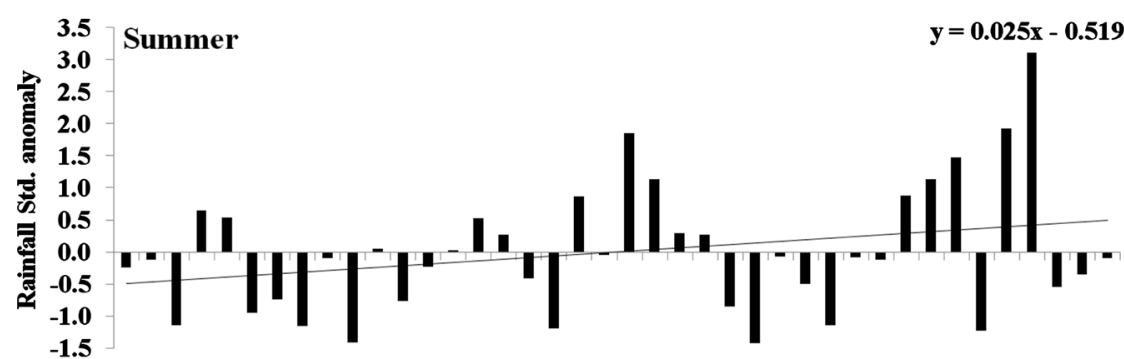

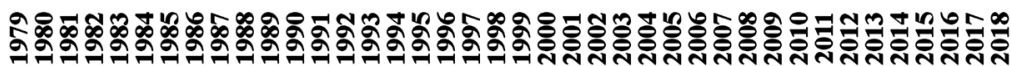

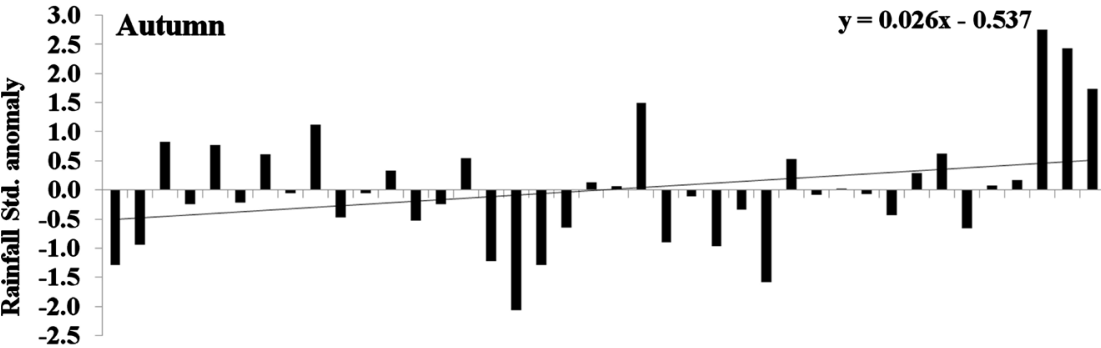

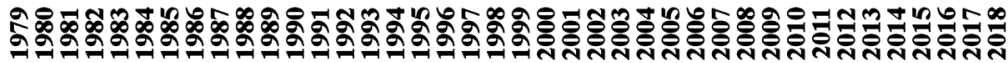

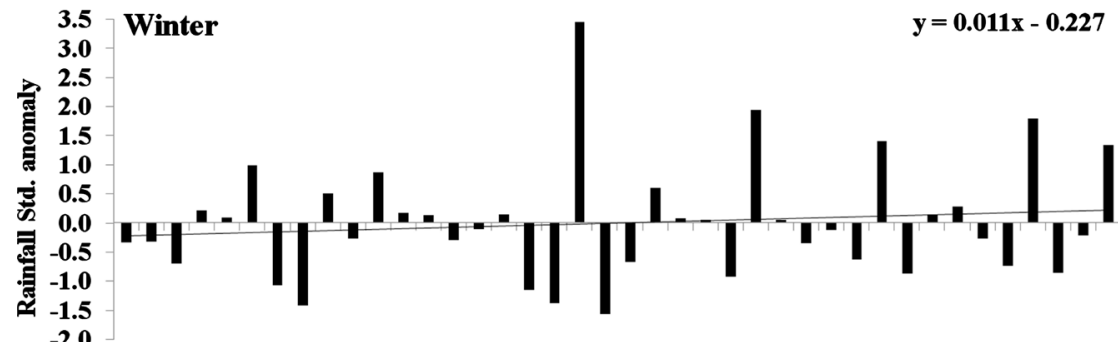

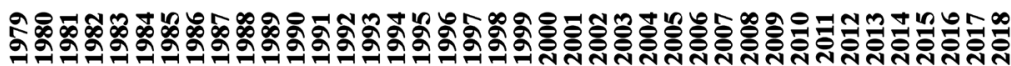

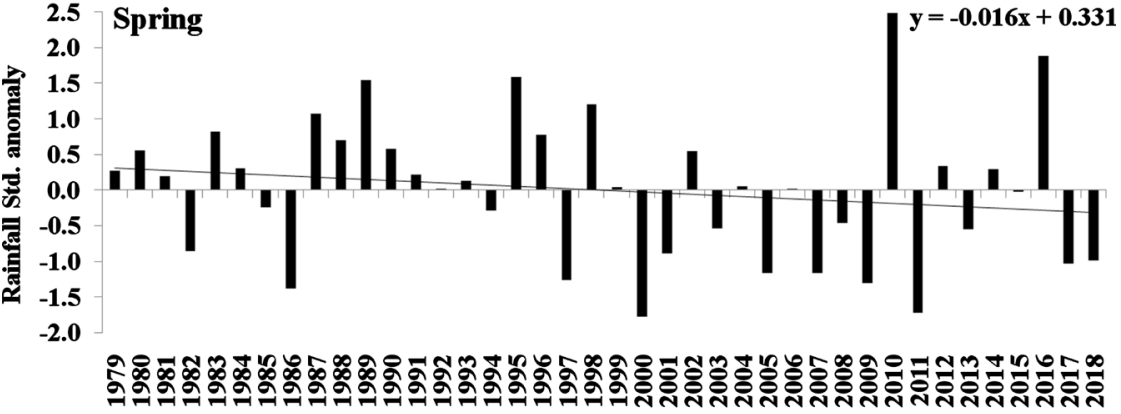

Figure 2. Standardized anomaly variations during different seasons over Zhoushan. 
except in the spring season. During the summer season, the affect of typhoon are higher and recent studies are explained that the intensity of the typhoons and the number of typhoons are increasing over the global scale [21] [22]. Other studies on ENSO effect on typhoons over northwest Pacific Ocean on the formation and intensity [23] [24] [25] [26] [27]. Higher number of typhoons forming over the northwest Pacific Ocean, it is observed that the mean number of typhoon formation during El Nino, La Nina and neutral years are 27, 22 and 26 respectively, however the rainfall over the land depends on the typhoon landfall or passing through. From the Figure 2 summer season anomalies, it is clearly seen that the rainfall occurred over Zhoushan is higher even in the strong El Nino years (eg. years 1997 and 2015), however most of El Nino years experiencing more than normal rainfall. In the La Nina years, the rainfall is lower than El Nino years, this may be due to the mean number of typhoons are lower. However in the neutral years the mean formation of typhoons is higher (lower than El Nino years) and the intensity of typhoons in the neutral years are lower.

\subsection{Annual and Decadal Variation of Rainfall over Zhoushan}

Annual variations are illustrating in the Figure 3. Figure 3 clearly showing the increasing trend. The annual rainfall is mainly depending on the typhoon passing through Zhoushan. Year 1986 received lowest rainfall. During the years 2003-2009 the annual rainfall is less than normal. From the year 2010, Zhoushan received higher rainfall except in the years 2011, 2013. However 2015 received highest rainfall than previous years.

Decadal variations are given in the Figure 4. From the figure, the recent decade experienced higher rainfall than previous decades. Increase in rainfall in the recent decade may be due to the typhoons landfall or passing through Zhoushan

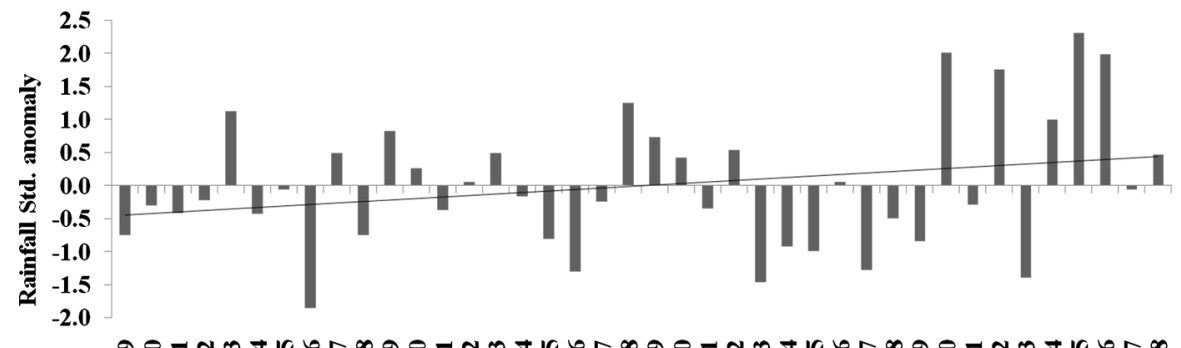

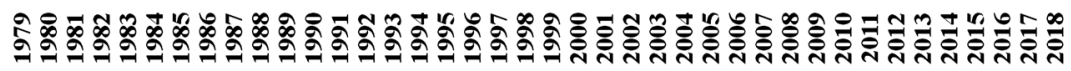

Figure 3. Annual variation of rainfall over Zhoushan.

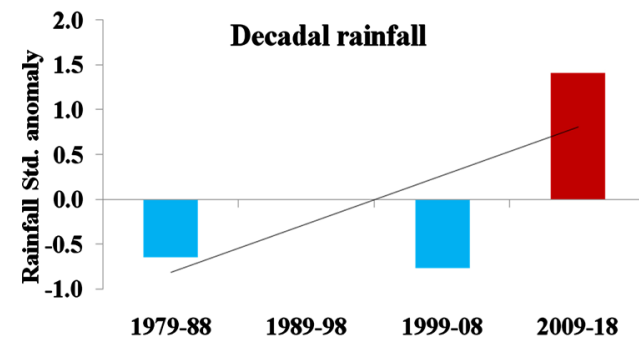

Figure 4. decadal variation of rainfall over Zhoushan. 
are more. At the same time, the convective rainfall and topographic effect of rainfall increased. The anomaly for the decade $1989-98$ is very low $(-0.0017)$, so the value is not visible in the figure.

\section{Case Studies of the Rainfall Variations Due to Typhoons over Zhoushan}

The formation mechanisms of the TC inner core and the outer rainbands are different. Within the inner core of the storm, the precipitation bands usually have growing convective cells on the upwind end and stratiform precipitation on the downwind end, thus displaying a distinct precipitation life cycle. The rainbands located far from the storm center are buoyancy-driven convective elements that appear influenced, but not constrained, by the cyclonic vortex circulation [28]. Several observational studies [29] [30] [31] suggest an increasing trend in TC rainfall and intensity in various regions. In this paper random case studies have been investigate the diurnal variations of TC using TRMM precipitation.

\subsection{Rainfall Variations Due to Typhoon Chan Hom}

Typhoon Chan-Hom generated over west Pacific and the landfall over Zhoushan (Zhujiajian) then weakens. While typhoon passing, before landfall, typhoon rainfall increased. However when the typhoon near to Zhoushan the rainfall decreased, is due the typhoon eye is bigger and while passing through and increase in rainfall when landfall. After passing through Zhoushan, the rainfall decreased as well as the intensity of typhoon also decreased. Higher rainfall occurred while the typhoon passing, before landfall, the typhoon is connected with the southwest monsoon and multiple typhoons in the early stage, making Chan-Hom have abundant water vapor supply. The release of latent heat of condensation is not uniform in the typhoon structure, which usually concentrated on the eyewall and some spiral bands around the typhoon eye area [32]. The region of divergence moisture during the typhoon Chan-Hom may be caused by the local wind convergence due to the complex topography (Figure 5).

\subsection{Rainfall Variations Due to Typhoon Damrey}

This case study is the typhoon Damrey passing through Zhoushan. Damrey is passing though little far away, but produced rainfall. Damrey intensified in East China Sea and produce rainfall over Zhoushan. This case is an example for the rainfall when typhoon passing through, however the rainfall is not much but it contributes for the monthly rainfall leading to annual rainfall (Figure 6).

\subsection{Rainfall Variations Due to Typhoon Fitow}

Typhoon Fitow is another case which produced rainfall over Zhoushan. Typhoon Fitow was landfall at Zhejiang province, which is lower latitude of Zhoushan. The rainfall occurred due to typhoon Fitow was around $160 \mathrm{~mm}$. higher rainfall occurred due to Fitow due the intensity of typhoon was higher (Figure 7). 

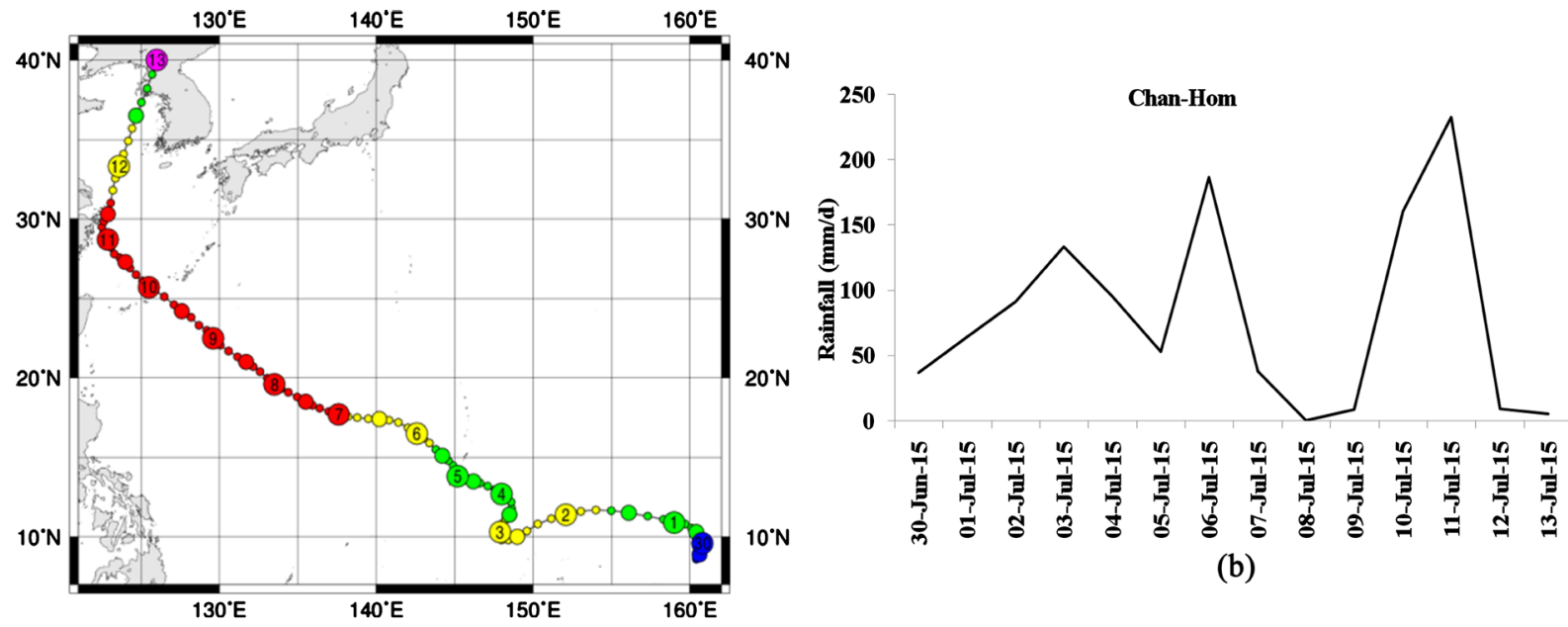

(a)

Figure 5. Case study 1: Daily rainfall variations over Zhoushan during the typhoon Chan-Hom. (a) Typhoon Chan-Hom track over the west Pacific Ocean, the numbers in the track represents the date. (b) Rainfall variation during the typhoon Chan-Hom life time.

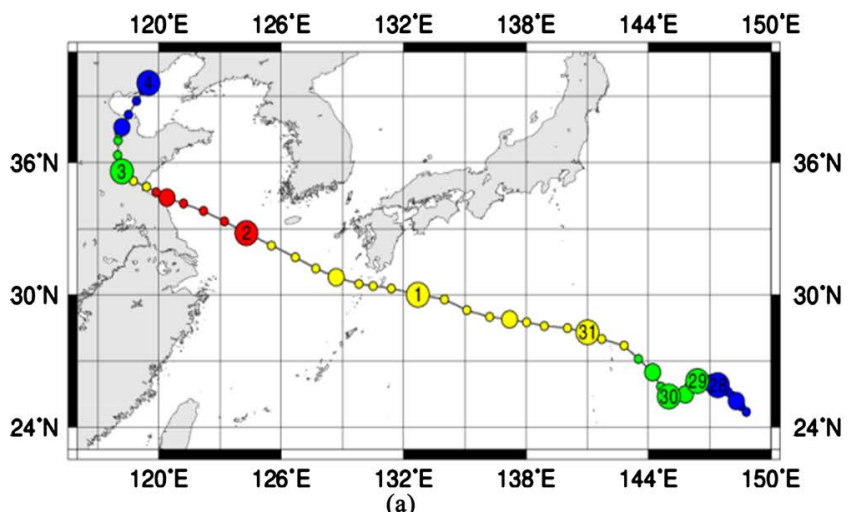

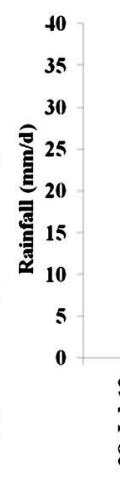

(a)

Figure 6. Case study 2: Daily rainfall variations over Zhoushan during the typhoon Damrey. (a) Typhoon Damrey track over the west Pacific Ocean, the numbers in the track represents the date. (b) Rainfall variation during the typhoon Damrey life time.

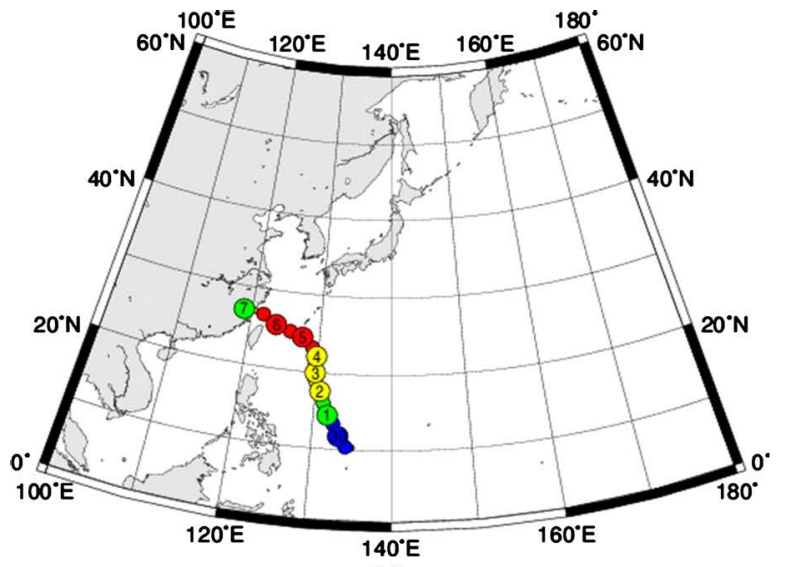

(a)

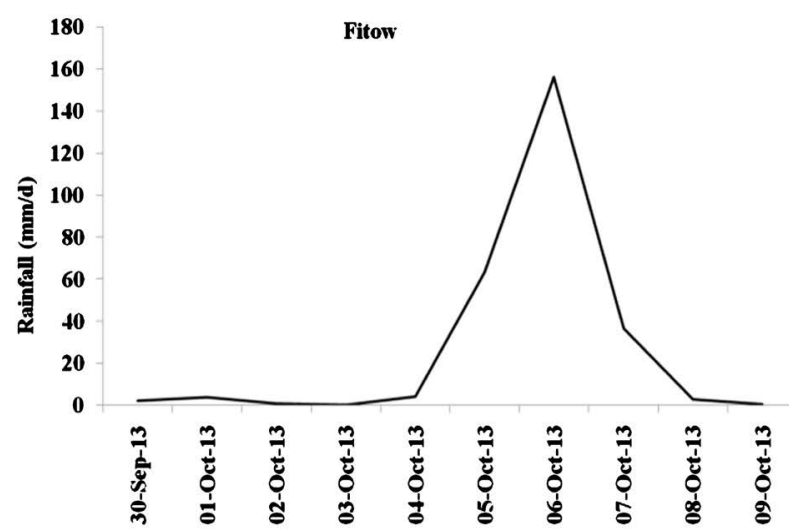

(b)

Figure 7. Case study 3: Daily rainfall variations over Zhoushan during the typhoon Fitow. (a) Typhoon Fitow track over the west Pacific Ocean, the numbers in the track represents the date. (b) Rainfall variation during the typhoon Fitow life time. 

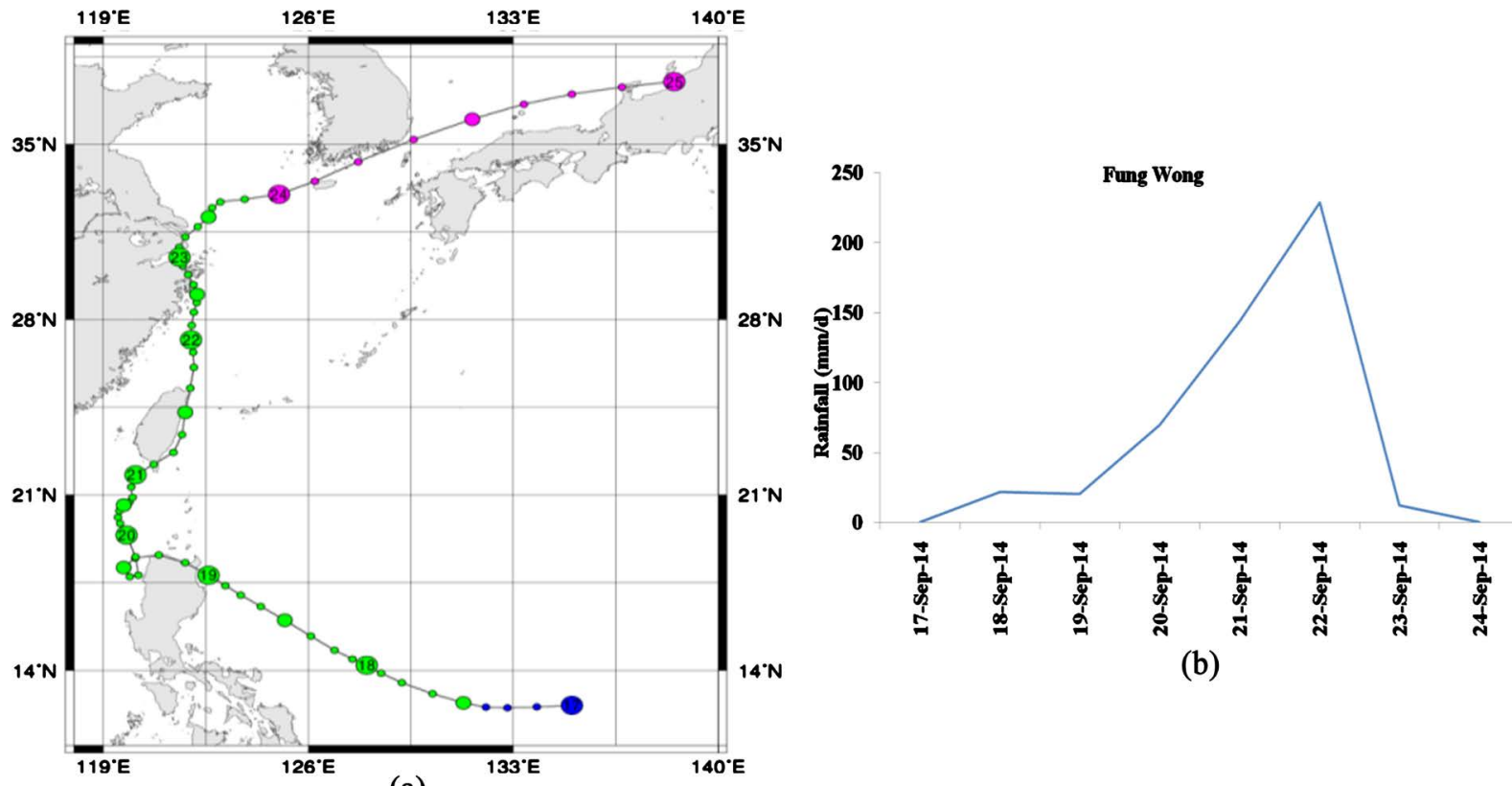

(b)

(a)

Figure 8. Case study 4: Daily rainfall variations over Zhoushan during the typhoon Fung Wong (a) Typhoon Fung Wong track over the west Pacific Ocean, the numbers in the track represents the date. (b) Rainfall variation during the typhoon Fung Wong life time.

\subsection{Rainfall Variations Due to Typhoon Fung Wong}

Typhoon Fung Wong is another typhoon which passing through Zhoushan over the land. Fung Wong intensity was low, however the rainfall occurred due to Fung Wong is higher. The rainfall slowly increased when it reached Zhejiang province, later when the intensity decreased the rainfall decreased (Figure 8).

From the above case studies, it is clear that when the typhoon landfall or passing through over Zhoushan produce rainfall. However the typhoon intensity also influences the rainfall.

\section{Conclusion}

Zhoushan is an island with different topography and convective rainfall patterns, however the main rainfall occurring over Zhoushan due to typhoons (landfall or passing through). Zhoushan is having rainfall over the summer mainly due to the typhoons. In recent years, there is an increasing trend in typhoons passing through Zhoushan with higher intensity. There is a decreasing trend in spring season due to the weather pattern extending. Annual rainfall pattern showing increasing trend, even though there are El Nino/La Nina, the rainfall over Zhoushan is not following. Decadal rainfall clearly indicating higher rainfall the recent decade (2009-2018) and there is increasing trend. Increase in rainfall in the recent decade is due to the higher intensity typhoons are passing through. The case studies are indicating that Zhoushan experienced rainfall due to typhoon passing through; however rainfall depends on the intensity of the typhoon. 


\section{Acknowledgements}

The authors express their gratitude to GPCP for monthly rainfall data and the NASA/Goddard Space Flight Center for providing TRMM daily rainfall data. The authors thank the editor and the anonymous reviewers for their comments that improved the original manuscript.

\section{Conflicts of Interest}

The authors declare no conflicts of interest regarding the publication of this paper.

\section{References}

[1] Villarini, G., Smith, J.A., Baeck, M.L., Marchok, T. and Vecchi, G.A. (2011) Characterization of Rainfall Distribution and Flooding Associated with U.S. Landfalling Tropical Cyclones: Analyses of Hurricanes Frances, Ivan, and Jeanne (2004). Journal of Geophysical Research: Atmospheres, 116, D23116. https://doi.org/10.1029/2011JD016175

[2] Englehart, P. and Douglas, A. (2001) The Role of Eastern North Pacific Tropical Storms in the Rainfall Climatology of Western Mexico. International Journal of Climatology, 21, 1357-1370. https://doi.org/10.1002/joc.637

[3] Prat, O.P. and Nelson, B.R. (2013) Precipitation Contribution of Tropical Cyclones in the Southeastern United States from 1998 to 2009 Using TRMM Satellite Data. Journal of Climate, 26, 1047-1062. https://doi.org/10.1175/JCLI-D-11-00736.1

[4] Steranka, J., Rodgers, E.B. and Gentry, R.C. (1986) The Relationship between Satellite Measured Convective Bursts and Tropical Cyclone Intensification. Monthly Weather Review, 114, 1539-1546. https://doi.org/10.1175/1520-0493(1986)114<1539:TRBSMC>2.0.CO;2

[5] Rao, R.V. and MacArthur, P.D. (1994) The SSM/I Estimated Rainfall Amounts of Tropical Cyclones and Their Potential in predicting the Cyclone Intensity Changes. Monthly Weather Review, 122, 568-1574. https://doi.org/10.1175/1520-0493(1994)122<1568:TSERAO >2.0.CO;2

[6] Kieper, M.E. and Jiang, H. (2012) Predicting Tropical Cyclone Rapid Intensification Using the $37 \mathrm{GHz}$ Ring Pattern Identified from Passive Microwave Measurements. Geophysical Research Letters, 39, L13804. https://doi.org/10.1029/2012GL052115

[7] Yang, G.Y. and Slingo, J. (2001) The Diurnal Cycle in the Tropics. Monthly Weather Review, 129, 784-801. https://doi.org/10.1175/1520-0493(2001)129<0784:TDCITT >2.0.CO;2

[8] Dai, A. (2001) Global Precipitation and Thunderstorm Frequencies. Part II: Diurnal Variations. Journal of Climate, 14, 1112-1128. https://doi.org/10.1175/1520-0442(2001)014<1112:GPATFP $>2.0 . C O ; 2$

[9] Nesbitt, S.W. and Zipser, E.J. (2003) The Diurnal Cycle of Rainfall and Convective Intensity According to Three Years of TRMM Measurements. Journal of Climate, 16, 1456-1475. https://doi.org/10.1175/1520-0442-16.10.1456

[10] Bowman, K.P., Collier, J.C., North, G.R., Wu, Q., Ha, E. and Hardin, J. (2005) Diurnal Cycle of Tropical Precipitation in Tropical Rainfall Measuring Mission (TRMM) Satellite and Ocean Buoy Rain Gauge Data. Journal of Geophysical Research: Atmospheres, 110, D21104. https://doi.org/10.1029/2005JD005763

[11] Gray, W.M. and Jacobson, R.W. (1977) Diurnal Variation of Deep Cumulus Con- 
vection. Monthly Weather Review, 105, 1171-1188. https://doi.org/10.1175/1520-0493(1977)105<1171:DVODCC >2.0.CO;2

[12] Randall, D.A., Harshvardhan and Dazlich, D.A. (1991) Diurnal Variability of the Hydrologic Cycle in a General Circulation Model. Journal of the Atmospheric Sciences, 48, 40-62. https://doi.org/10.1175/1520-0469(1991)048<0040:DVOTHC >2.0.CO;2

[13] Chen, S.S. and Houze, R.A. (1997) Diurnal Variation and Lifecycle of Deep Convective Systems over the Pacific Warm Pool. Quarterly Journal of the Royal Meteorological Society, 123, 357-388. https://doi.org/10.1256/smsqj.53805

[14] Sui, C.-H., Lau, K.-M., Takayabu, Y.N. and Short, D.A. (1997) Diurnal Variations in Tropical Oceanic Cumulus Convection during TOGA COARE. Journal of the Atmospheric Sciences, 54, 639-655. https://doi.org/10.1175/1520-0469(1997)054<0639:DVITOC>2.0.CO;2

[15] Wang, Y. (2009) How Do Outer Spiral Rainbands Affect Tropical Cyclone Structure and Intensity? Journal of the Atmospheric Sciences, 66, 1250-1273. https://doi.org/10.1175/2008JAS2737.1

[16] Huffman, G.J., Adler, R.F., Morrissey, M., Bolvin, D.T., Curtis, S., Joyce, R., McGavock, B. and Susskind, J. (2001) Global Precipitation at One-Degree Daily Resolution from Multi Satellite Observations. Journal of Hydrometeorology, 2, 36-50. https://doi.org/10.1175/1525-7541(2001)002<0036:GPAODD>2.0.CO;2

[17] Huffman, G.J., Adler, R.F., Bolvin, D.T., Gu, G., Nelkin, E.J., Bowman, K.P., Hong, Y., Stocker, E.F. and Wolff, D.B. (2007) The TRMM Multi-Satellite Precipitation Analysis: Quasi-Global, Multi-Year, Combined-Sensor Precipitation Estimates at Fine Scale. Journal of Hydrometeorology, 8, 38-55. https://doi.org/10.1175/JHM560.1

[18] Shepherd, J.M., Grundstein, A. and Mote, T.L. (2007) Quantifying the Contribution of Tropical Cyclones to Extreme Rainfall along the Coastal South-Eastern United States. Geophysical Research Letters, 34, L23810. https://doi.org/10.1029/2007GL031694

[19] Jiang, H., Ramirez, E.M. and Cecil, D.J. (2012) Convective and Rainfall Properties of Tropical Cyclone Inner Cores and Rainbands from 11 Years of TRMM Data. Monthly Weather Review, 141, 431-450. https://doi.org/10.1175/MWR-D-11-00360.1

[20] Chu, J.H., Sampson, C.R., Levine, A.S. and Fukada, E. (2002) The Joint Typhoon Warning Center Tropical Cyclone Best-Tracks, 1945-2000 (Rep. NRL/MR/7540-0216). Joint Typhoon Warning Center, HI. http://www.usno.navy.mil/NOOC/nmfc-ph/RSS/jtwc/best tracks/TC bt report.html

[21] Webster, P.J., Holland, G.J., Curry, J.A. and Chang, H.R. (2005) Changes in Tropical Cyclone Number, Duration, and Intensity in a Warming Environment. Science, 309, 1844-1846. https://doi.org/10.1126/science.1116448

[22] Trenberth, K. (2005) Uncertainty in Hurricanes and Global Warming. Science, 308, 1753-1754. https://doi.org/10.1126/science.1112551

[23] Pudov, V.D. and Petrichenko, S.A. (1998) Relationship between the Evolution of Tropical Cyclones in the Northwestern Pacific and El Niño. Oceanology, 38, 447452.

[24] Pudov, V.D. and Petrichenko, S.A. (2001) 1997-1998 El Niño and Tropical Cyclone Genesis in the Northwestern Pacific. Izvestiya, Atmospheric and Oceanic Physics, 37, 576-583.

[25] Chan, J.C.L. (2000) Tropical Cyclone Activity over the Western North Pacific Asso- 
ciated with El Niño and La Niña Events. Journal of Climate, 13, 2960-2972. https://doi.org/10.1175/1520-0442(2000)013<2960:TCAOTW >2.0.CO;2

[26] Ha, K.J., Yoon, S.J., Yun, K.S., Kug, J.S., Jang, Y.S. and Chan, J.C.L. (2012) Dependency of Typhoon Intensity and Genesis Locations on El Niño Phase and SST Shift over the Western North Pacific. Theoretical and Applied Climatology, 109, 383-395. https://doi.org/10.1007/s00704-012-0588-Z

[27] Hsu, P.C., Ho, C.R., Liang, S.J. and Kuo, N.-J. (2013) Impacts of Two Types of El Niño and La Nina Events on Typhoon Activity. Advances in Meteorology, 2013, Article ID: 632470. https://doi.org/10.1155/2013/632470

[28] Houze Jr., R.A. (2010) Clouds in Tropical Cyclones. Monthly Weather Review, 138, 293-344. https://doi.org/10.1175/2009MWR2989a.1

[29] Kim, J.-H., Ho, C.-H., Lee, M.-H., Jeong, J.-H. and Chen, D. (2006) Large Increase in Heavy Rainfall Associated with Tropical Cyclone Landfalls in Korea after the Late 1970s. Geophysical Research Letters, 33, L18706.

https://doi.org/10.1029/2006GL027430

[30] Lau, W.K.-M. and Zhou, Y.P. (2012) Observed Recent Trends in Tropical Cyclone Rainfall over the North Atlantic and the North Pacific. Journal of Geophysical Research: Atmospheres, 117, D03104. https://doi.org/10.1029/2011JD016510

[31] Lau, W.K.-M. and Wu, H.-T. (2008) Have Tropical Cyclones Been Feeding More Extreme Rainfall? Journal of Geophysical Research: Atmospheres, 113, D23113. https://doi.org/10.1029/2008JD009963

[32] Marks Jr., F.D. (1985) Evolution of the Structure of Precipitation in Hurricane Allen (1980). Monthly Weather Review, 113, 909-930. https://doi.org/10.1175/1520-0493(1985)113<0909:EOTSOP $>2.0 . C O ; 2$ 